\title{
家鬼膀胱尿管移行部への拡張・切開操作による影響
}

\author{
日本医科大学泌尿器科学教室 (主任・指導 : 秋元成太教授)
}

広 瀬 始之

\section{AN EXPERIMENTAL STUDY OF THE INFLUENCE OF DILATATION AND INCISION TO VESICOURETERAL JUNCTION IN RABBITS}

\author{
Haruyuki Hirose \\ Department of Urology, Nippon Medical School \\ (Director: Prof. M. Akimoto)
}

The influence of dilatation and incision to vesicoureteral junction in rabbits was studied radiologically and histopathologically. Each 12 Japanese white rabbits were submitted to one of the following procedures to the left ureteral orifice.

1) Dilatation up to $10 \mathrm{~F}$

2) Dilatation up to $7 \mathrm{~F}$

3) Incision of submucosal ureter

As for the radiological examination, cystography and IVU were performed on the 1st and 3rd days and in the 1st, 2nd, 4th and 8th weeks after operation. In the radiological examination, VUR was observed in 8 of 12 amimals in 10F dilatation group. Dilatation of the upper urinary tract was seen in 10 animals including 4 without VUR. No VUR was observed in the 7F dilatation group and incision group.

As for the histopathological examination, the bladder and ureter were excised after radiological examination. In the $10 \mathrm{~F}$ dilatation group, damage and fibrosis of intramural ureteral muscle layers were observed, which might be due to laceration of the ureteral wall by excessive dilatation. Furthermore, the area of muscle layers in a cross section of the intramural ureter was significantly decrased in the $10 \mathrm{~F}$ dilatation group compared with control $(\mathrm{p}<0.01)$. In the $7 \mathrm{~F}$ dilatation group and incision group, histopathological change of the interamural ureter were insignificant.

Comparing the human ureter with the rabbit ureter, $7 \mathrm{~F}$ dilatation in the rabbit is comparable to $16 \mathrm{~F}$ dilatation in humans which is the maximum size dilatation in ordinary cases of dilatation of the ureteral orifice. While, $10 \mathrm{~F}$ dilatation in rabbits is comparable to the extraordinarily huge $24 \mathrm{~F}$ dilatation in humans.

In conclusion, it is suggested, from the present experiment using rabbits, that the usual procedure of dilatation and incision to the vesicoureteral junction in humans seems to have insignificant influence on the urinary tract.

要旨: 家鬼を以下の 3 群にわけて, 尿管口に対する払張, 切開操作による尿路系への影響について検討 した。 1） $10 \mathrm{~F}$ 拡張群，2） $7 \mathrm{~F}$ 拡張群，3）切開群

$\mathrm{X}$ 線学的検索として，術後 1 日目， 3 日目，1，2，4，8 週目にて各群 2 羽ずつ計 12 羽，膀胖造影， 排泄性尿路造影 (IVU)を施行した。 $10 \mathrm{~F}$ 抁張群では 12 例中 8 例に VUR 認め, 12 例中 10 例に上部尿路 の拡張を認めた。 $7 \mathrm{~F}$ 拡張群, 切開群ではVURの発現したものはなかった。

病理組織学的検索については, X 線学的検索の直後の膀胱を摘出して検討した。 $10 \mathrm{~F}$ 拡張群では過度 の払張により, 尿管壁の断裂による筋層の損傷, 線維化が認められ, 壁内尿管筋層の全層に対する面積 比は有意に減少していた。これに比較して, $7 \mathrm{~F}$ 㧪張群, 切開群では壁内尿管の組織学的変化は軽微であっ た。

ヒト尿管と家鬼尿管との比較検討上, 尿管内径と拡張との比率からみると $10 \mathrm{~F}$ 拡張群は, ヒトにあては 
めると過度の拡張を負荷していると拈われる。家鬼尿管7F 拡張は, 拡張の程度からみて, ヒトに拈ける 尿管鏡施行時の通常の尿管口拡張操作にほぼ相当するものと推測される.

以上の結果から考劣ると, ふつら扔こなわれるヒト尿管口拡張, 切開操作では, 尿路系への影響は少 なく, 安全性にもほぼ問題ないものと推測される.

\section{緒 言}

内視鏡を経尿道的に尿管内へ挿入する操作は古くか ら試みられている。1970年代より視野が良好でかつ操 作用チャンネルを持った硬性尿管鏡が開発され，悪性 腫瘍の診断に加光て結石摘出術への応用がなされてき ている。

尿管鏡を施行するにあたっては，当然ながらまず尿 管鏡が尿管口を通過するか否かが大きなポイントとな る，尿管鏡施行に先立ち尿管口を拡張する操作が重要 であるとの報告1)もあが，拡張することに対して消 極的な意見2)少なくなく，尿管鏡施行後の膀胱尿管 逆流 (VUR と略) の発現など尿管鏡操作による尿路系 への重要な影響に関してはいまだあきらかではない。 この点を追究すべく，家鬼を用いて次の実験を拈こ なった，家鬼尿管口の拡張・切開操作を抗こない，尿 路系に与える影響について，X 線学的ならびに病理組 織学的に検索したので報告する.

\section{実験方法}

実験材料は体重 $3.6 \pm 0.3 \mathrm{~kg}$ の雄性成熟家鬼(日本白 色種）を使用した。すべて術前に膀胱造影および静脈 性尿路造影（IVU と略）を施行し尿路系に著変のない 家鬼を選び，麻酔下にて以下の手術を施行した。麻酔 はすべてペントバルビタール静脈麻酔とし, 原則的に $30 \mathrm{mg} / \mathrm{kg}$ を耳静脈より投与した。 下腹部横切開にて 膀胱を露出し, 膀胱前壁に約 $3 \mathrm{~cm}$ の縦切開をおこなっ た後, 尿管走行を確認し切開・払張操作を容易にする ために, 実験群はすべて左尿管口から逆行性に直径 0.025インチガイドワイヤーを挿入した. 実験群を以下 の 3 群に分け，一群につき最低12羽を使用した。

\section{1) $10 \mathrm{~F}$ 拡張群}

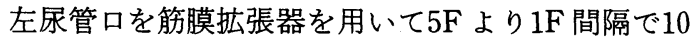
$\mathrm{F}$ まで拡張した。

\section{2) $7 \mathrm{~F}$ 拡張群}

左尿管口を筋膜拡張器を用いて $5 \mathrm{~F}, 6 \mathrm{~F}, 7 \mathrm{~F}$ の 3 段階 に拡張した。

\section{3）切開群}

膀胱粘膜下尿管の上壁を, 鋭的に尿管口より約 $5 \mathrm{~mm}$ にわたり切開した。

3 群ともに膀胱を4-0クロミックにて一層縫合し, 腹
壁は 4 号絹糸にて二層縫合をおこなった。

\section{A. X 線学的検索}

手術後 1 日目・ 3 日目ならび $1 ・ 2 ・ 4$ 打よび 8 週 目に各群 2 羽ずつ膀胼造影, IVUを括こなった。造影 剂は $66.8 \mathrm{~W} / \mathrm{V} \%$ イタラム酸ナトリウム(コンレイ 400）を使用した。膀胱造影は経尿道的にネラトン氏カ テーテルを挿入し膀胱を空虚にした後, 造影剂 $5 \mathrm{ml}$ と 生理食塩水 $45 \mathrm{ml}$ を膀胼内に注入し VUR の存在と程 度をみた，VURの程度は国際分類 ${ }^{3}$ （表 1 ）により判 定した. その後, IVUは耳介静脈より造影剂を $1 \mathrm{ml} / \mathrm{kg}$ 注入し，15分後に撮影した。

B. 病理組織学的検索

1. 光顕的観察

$\mathrm{X}$ 線学的検索の直後屠殺して膀胼を摘出し，10\%ホ ルマリンにて固定した後パラフィンに包埋した。膀胱 尿管移行部を観察するため膀胱壁内尿管長軸に対し水 平方向の輪切の連続標本を作製し，へマトキシリン・ エオジン (Hematoxylin eosin, H.E.) 染色, アザン (Azan)染色, エラスチカ・ワンギーソン (elastica Van Gieson）染色を怙こなった。

2. 膀脱壁内尿管に和ける筋層の面積比

膀胱壁内尿管の筋層の損傷の程度を客観評価する目 的で, 術後 2 週目以後の全例に対し壁内尿管に拈ける 筋層の占める面積比を求めた。一検体につき各々 5 ケ 所の標本についてアザン染色を施行した各標本を拡 大, 写真撮影を拈こない, 膀脂壁内尿管の全周および 笳層をトレースして, 各々の面積を Image Analyzer

表 1 国際分類 ${ }^{3)}$ によるVUR の Grading

\begin{tabular}{|c|c|}
\hline Grade I & 逆流は尿管のみ \\
\hline Grade II & $\begin{array}{l}\text { 逆流は腎孟，尿管まで認めるが，尿管，腎孟， } \\
\text { 腎杯の拡張は認めない. }\end{array}$ \\
\hline Gr & $\begin{array}{l}\text { 尿管の軽度拡張または蛇行, および腎杯の軽度 } \\
\text { 鈍円化を認める. }\end{array}$ \\
\hline Grac & $\begin{array}{l}\text { 尿管の中等度拡張または蛇行を認める. 腎杯は } \\
\text { 桿棒状に払張し, 鋭角が消失するが, 乳頭状形 } \\
\text { 態は存在する. . }\end{array}$ \\
\hline Gro & $\begin{array}{l}\text { 尿管の高度拡張扣よび蛇行を認め, 腎孟, 腎杯 } \\
\text { は高度に拡張し, 腎杯の乳頭状の形態も消失し } \\
\text { ている. }\end{array}$ \\
\hline
\end{tabular}


表 2 X線学的所見

\begin{tabular}{|c|c|c|c|c|c|c|}
\hline 実験群 & \multicolumn{2}{|c|}{$10 \mathrm{~F}$ 払張群 } & \multicolumn{2}{|c|}{$7 \mathrm{~F}$ 払張群 } & \multicolumn{2}{|c|}{ 切 開 群 } \\
\hline $\begin{array}{c}\text { 操作後 } \\
\text { 線 } \\
\text { 期間 }\end{array}$ & VUR & $\begin{array}{c}\text { 上部尿路* } \\
\text { 执張 }\end{array}$ & VUR & $\begin{array}{c}\text { 上部尿路* } \\
\text { 执張 }\end{array}$ & VUR & $\begin{array}{l}\text { 上部尿路* } \\
\text { 㧨張 }\end{array}$ \\
\hline 1 日目 & - & $\begin{array}{l}+ \\
+\end{array}$ & - & $\begin{array}{l}+ \\
+\end{array}$ & - & - \\
\hline 3 日目 & $\begin{array}{c}\text { Grade II } \\
-\end{array}$ & $\begin{array}{l}- \\
+\end{array}$ & - & - & - & - \\
\hline 1 週目 & $\begin{array}{c}\text { Grade III } \\
-\end{array}$ & $\begin{array}{l}+ \\
+\end{array}$ & - & - & - & - \\
\hline 2 週目 & $\begin{array}{l}\text { Grade IV } \\
\text { Grade III }\end{array}$ & $\begin{array}{l}+ \\
+\end{array}$ & $\begin{array}{l}- \\
-\end{array}$ & - & - & - \\
\hline 4 週目 & $\begin{array}{l}\text { Grade III } \\
\text { Grade II }\end{array}$ & + & - & - & - & - \\
\hline 8 週目 & $\begin{array}{l}\text { Grade IV } \\
\text { Grade III }\end{array}$ & $\begin{array}{l}+ \\
+\end{array}$ & - & - & - & - \\
\hline
\end{tabular}

*IVU 所見により判定

（Microvideomat 2, CarlZeiss 社，西独）を用いて算 出した。計算は次の方法で招こなった。

壁内尿管筋層面積比=尿管笳層の面積/尿管全体の 面積

得られた結果は平均値士標準偏差で示し，有意差の 検定はStudent $\mathrm{t}$ test にて計算した。 また対照群とし て無処置の家鬼 3 羽につき同様の方法にて壁内尿管筋 層面積比を算出した。

\section{結 果}

\section{A. X 線学的検索 (表 2) \\ 1. $10 \mathrm{~F}$ 拡張群}

$10 \mathrm{~F}$ 払張群では術後 3 日目, 1 週目にて 2 例中 1 例, 術後 2 週目以後の全例に Grade II IV の VUR を認 めた（図 1 )。 また, IVU 上 2 例をのぞき全例に上部尿 路の拡張を認めた（図 2 ).

\section{2. $7 \mathrm{~F}$ 拡張群}

12例中 VURを認めたものはなかったＩVUにおい て術後 1 日目に軽度の上部尿路払張を認めたが， 3 日 目以後の10例には明らかな払張は認めなかった（図 3 ).

\section{3. 切開群}

膀胱造影にて 12 例中 VUR を認めたものは 1 例もな く，12例すべてにおいて，IVU 上明らかな異常所見は 認めなかった。

B. 病理組織学検索

1. 光顕的観察

1) $10 \mathrm{~F}$ 拡張群
術後 1 日目では拡張操作により尿管壁の全層性の断 裂が認められ，同部からの出血により内腔は凝血塊で 満たされ，また好中球を中心とした小円形細胞浸潤も 認められた。ささに，上皮は一部を残し剝離，脱落し ていた（図4）.

術後 3 日目には出血部の赤血球はかなり吸収され， フィブリンの析出が目立つ様になった．好中球の浸潤 は一層著明となり，大食細胞の増殖が認められた。創 部の壁は浮腫状となり一部で線維芽細胞の出現がみら れ，ごく一部で残存した上皮から損傷部に沿った再生 像も観察された（図 5 ).

術後 1 週目では出血部の赤血球はほとんど吸収さ れ，断裂部を中心に炎症性肉芽組織の形成が認められ た。好中球はほとんど消失して括り, 細胞浸潤は赤血 球などを筫食する大食細胞を中心とするものであっ た。肉芽組織に沿って上皮の再生もみられた（図 6 ). 術後 2 週目では筇層を含む断裂部は肉芽組織に置換 され，へモジデリンを負食する大食細胞，好酸球，リ ンパ球を中心とする小円形細胞浸潤を伴っていた。

術後 4 週目では断裂部の筋層を含む損傷部は完全に 線維性肉芽組織に置換され，上皮細胞は再生増殖を示 し表層を被覆していた（因7）（困 8).

\section{2. $7 \mathrm{~F}$ 拡張群}

術後 1 日目， 3 日目において出血，好中球を主とし た小円形細胞の浸潤を認めるが $10 \mathrm{~F}$ 払張群と比べ軽度 であり，さらには尿管壁の断裂も軽度で筋層にはおよ んでいなかった（図9）。 
術後 1 週目には小範囲に炎症性肉芽組織の形成がみ られるが，筋層の損傷はほとんど認められなかった。

術後 2 週目以後ではきわめて軽度の粘膜下線維化を 認めたのみで，尿管筋層に著変はみられなかった（図 10).

\section{3。切開群}

術後 1 日目， 3 日目には粘膜下尿管の切開部に一致 して尿管壁の損傷, 出血を認めたが(図11), 壁内尿管 には明らかな変化もなく, 術後 2 週目以後は, 切開部 の損傷も粘膜下尿管に部分的な線維化を認める以外著 変は認められなかった。

\section{4. 壁内尿管筋層の面積比}

無処置対照群の壁内尿管筋層面積比の平均值は $23.8 \pm 2.6 \%$ であった。7F 拡張群, 切開群については対 照群に比べて有意差を認めなかった。

$10 \mathrm{~F}$ 拡張群では術後 2 週目以後のすべてにおいて, 面積比を検討すると, 対照群および7F 拡張群, 切開群 に比し有意な減少を認めた（ $(\mathrm{p}<0.01 ） （$ 表 3$)$ 。

\section{考 察}

経尿道的に内視鏡を尿管内に插入することは，1912 年 Young らがはじめて試みている。以後数多くの改 良, 進歩がなされたが, 1970年代にはいり広視野で細 径の尿管鏡が開発され尿管内操作が直視下でおこなう ことが可能となった。近年尿管鏡を用いた結石摘出な ぞへの利用が Perz-Castero ${ }^{4)}$, Huffmann ら ${ }^{5)}$ の報告を 始めとして引き続き数多くの発表がなされている.

Lyon らは尿管鏡操作を成功させるには尿管口を充分 に拡張させることが重要であると述べている1)。これ ら尿管鏡操作に先立ち尿管口の拡張が広く扣こなわれ てきた。尿管口拡張操作について Carter $ら^{6}$ ) 125 例 の尿管結石に対し，ほとんどの症例で尿管鏡施行前に 尿管口の拡張を捛こなったが，尿管狭窄を 5 例に認め たのみで, VURが発現したものはなかったと報告し ている。一方, Stackl ら 2 は尿管口の拡張により 42 例中 2 例に VUR の発現を認め，拡張操作は尿管口に損傷 を与える可能性があるとして，尿管口の拡張には消極 的な見解もある。以上のように尿管鏡操作による尿路 系へ与光る影響に関してはいまだ充分に検討されてい るとはいい難い。

正常ヒトの壁内尿管に打けるの最小内径はおよそ4 Fであり，今回の実験対象とした家鬼の壁内尿管の径 はおよそ0.6mmである。内径と拡張の比率からみれ ば， $10 \mathrm{~F}$ 拡張群はヒトでは拈よそ $24 \mathrm{~F} に ， 7 \mathrm{~F}$ 拡張群は ヒトでは抢よそ $16 \mathrm{~F}$ の拡張に相当する。この比率から
表 3 膀胱壁内尿管に拈ける筇層の面積比(\%)

\begin{tabular}{|c|c|c|c|c|}
\hline 操作後期間 & 実験群 & $10 \mathrm{~F}$ 拡張群 & $7 \mathrm{~F}$ 拡張群 & 切 開 群 \\
\hline 2 週 & 目 & $10.8 \pm 1.3$ & $23.2 \pm 3.8$ & $23.6 \pm 2.0$ \\
\hline 4 週 & 目 & $10.9 \pm 4.6$ & $25.2 \pm 2.2$ & $24.2 \pm 1.6$ \\
\hline 8 週 & 目 & $12.6 \pm 2.3$ & $22.6 \pm 2.2$ & $24.9 \pm 1.3$ \\
\hline
\end{tabular}

(平均値士標準偏差)

みれば次のように考兄られる。すなわち尿管鏡操作に 伴う尿管口の拡張は一般的に $12 \sim 16 \mathrm{~F}$ まで招こなら が, 家鬼 $10 \mathrm{~F}$ 拡張群では壁内尿管に対し過度の拡張を， 家鬼7F 拡張群は通常のヒトの尿管口拡張とほぼ同等 の拡張を与光たものと推測しらる。

$10 \mathrm{~F}$ 拡張群では12例中 8 例に VUR が発現し, 組織 学的には壁内尿管全長にわたり筋層を中心として著明 な損傷，線維化が証明されておりその影響を示してい る。

VUR の防止機構や発生機序に関しては，古くから 多種多様の検索がなされてきた。例学ば膀脱壁内尿管 自身の機能もVUR 防止の重要な要因として考兄られ ている。板谷 ${ }^{7}$ は正常者および原発性 VUR 患者の壁内 尿管の病理組織学的検索を拈こない，つぎの結果を得 ている。すなわち VUR 患者では壁内尿管の筋層に発 育不全, 配列異常, 線維化等を認め, 尿管の伸展性, 筋緊張，長軸方向への蠕動運動が障害され壁内尿管内 腔が常に開存した形の硬いゴムチューブ状になってい ることが VUR の原因ではないかとしている。

本実験より VUR の発現について，10F 拡張群の病 理組織学的検索でも明らかなように壁内尿管の筋組織 の占める面積が有意に減少していた。これらの組織学 的変化は，板谷の報告した原発性 VUR の壁内尿管の 組織所見と酷似している。さらに $10 \mathrm{~F}$ 拡張群では膀胱 壁内尿管筋層を中心とする線維化を認め，これが VUR の原因と推測された。

$7 \mathrm{~F}$ 拡張群についてはVURの発現を認めたものは なく,術後 3 日目以後はIVU にて上部尿路拡張は認め なかった。病理組織学的検索でも10F 拡張群にみられ たような壁内尿管の断裂等の損傷は軽微で，尿管筋層 の変化はほとんど認めなかった。従って本実験の結果 から推察すると，ヒトに対しても通常の尿管鏡使用時 に打ける尿管口拡張操作では，尿路系へ与兄る影響は 少ないものと考光られた。

尿管鏡操作が困難な症例に，時に尿管口を切開する ことが怙こなわれてきた。しかし通常，粘膜下尿管は 

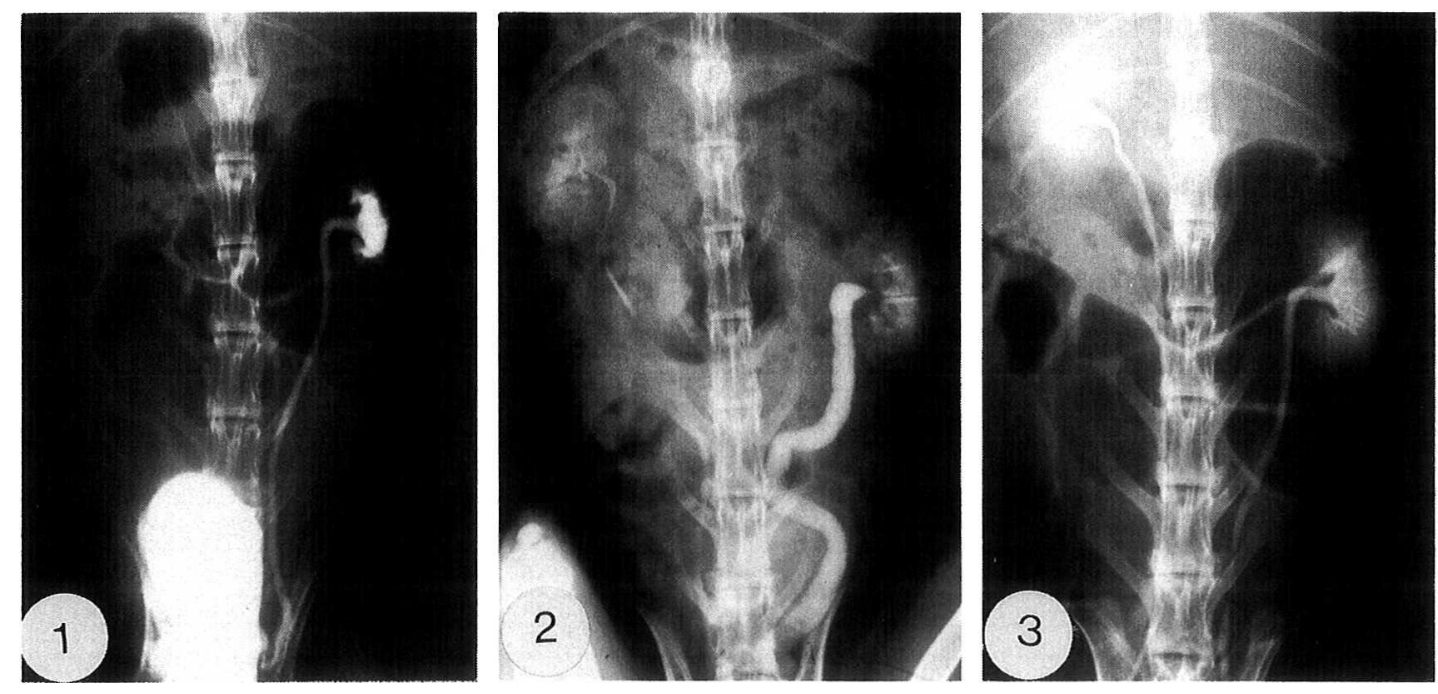

図 1 膀胱造影, $10 \mathrm{~F}$ 拡張群 4 週目

図 2 IVU, 10F 抎張群 8 週目

図 3 IVU, $7 \mathrm{~F}$ 拡張群 8 週目

図 $410 \mathrm{~F}$ 拡張群 1 日目. Azan 染色 $\times 10$

図 $510 \mathrm{~F}$ 拡張群 3 日目. Azan 染色 $\times 10$

図 $610 \mathrm{~F}$ 拡張群 1 週目. Azan 染色 $\times 10$
図 7 10F 拡張群 4 週目. Azan 染色 $\times 10$

図 8 図 7 の対側尿管. Azan 染色 $\times 10$

図 $97 \mathrm{~F}$ 拡張群 3 日目。 Azan 染色 $\times 10$

図10 7F 拡張群 4 週目. Azan 染色 $\times 10$

図11 切開群 3 日目, Azan 染色 $\times 10$ 

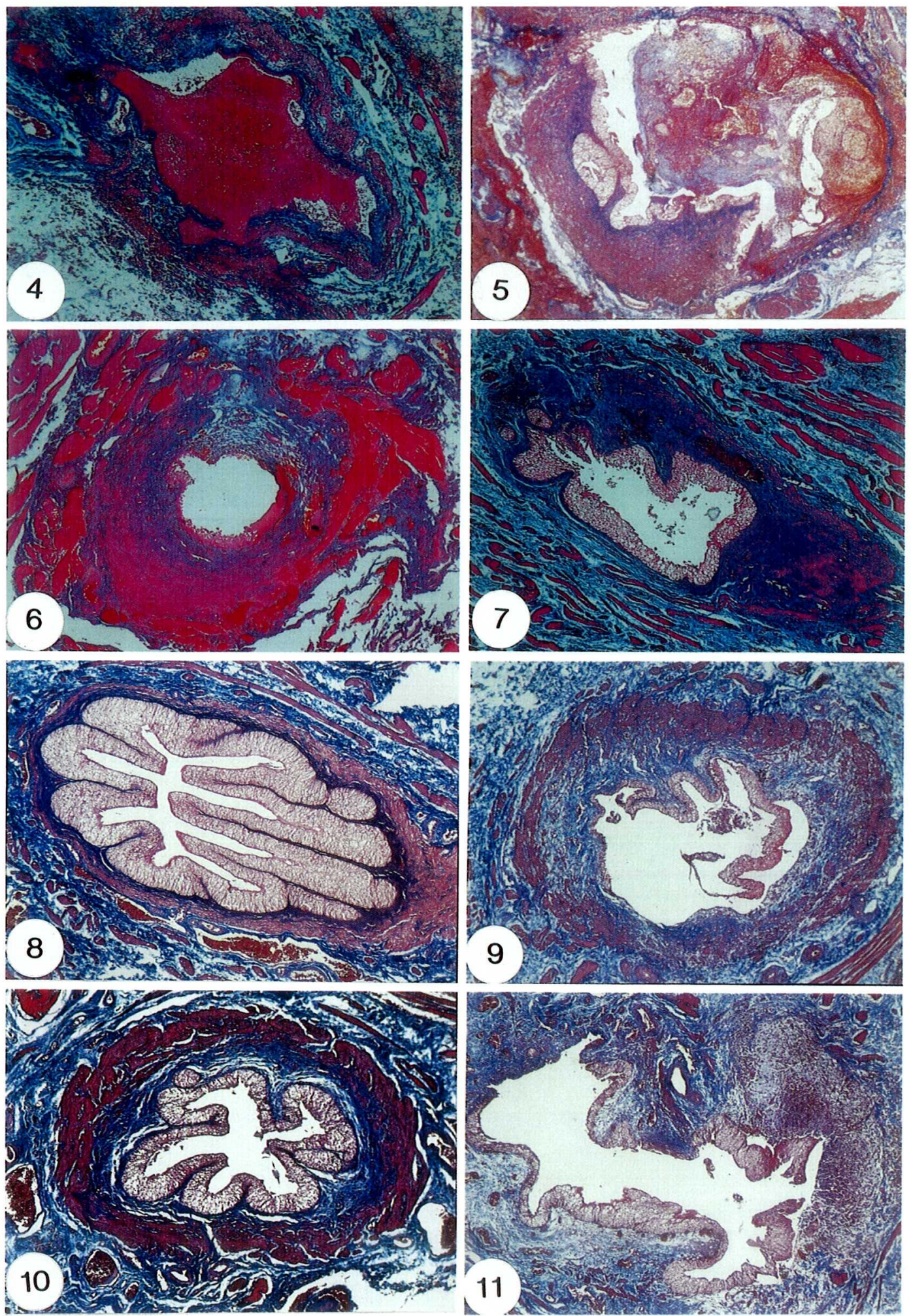
VUR 防止機構の重要な役割をはたしているものとさ れている。

Stephens ら ${ }^{8)}$ は VUR を認めた患者では粘膜下尿管 の筋細胞の欠如あるいは同部尿管筋線維の楔状の欠損 の存在することがVURの原因と述べている。

Witherington ${ }^{9}$ は，イヌに执いて粘膜下尿管の切除に より62例中44例にVUR を惹起せしめている。実験的 には尿管口切開により，VURの発現が高率にみられ るとの報告は多い10).

一方 Scott ら ${ }^{11) 12)}$ はイヌの実験で粘膜下尿管を完全 に切開した場合でも，尿管機能が正常であればVUR は生じないと述べ，Roberts ら ${ }^{13)}$ は尿管が正常ならば 粘膜下尿管の切開によるVUR の発現頻度は低いとし ている。本邦でも滝本 ${ }^{14)}$ は壁内尿管に損傷が及ばぬか ぎり，粘膜下尿管の切開のみではVUR は必ずしも発 現しないであろうと述べて扔り，酒井 ${ }^{15)}$ も又で粘膜 下尿管の切開を 10 例に施行し， 2 例にしか VUR の発 現をみなかったと報告している。本実験に扔いて，切 開群では12例中 1 例もVUR の発現を認めたものはな かった. したがって本実験の結果から推測すると，粘 膜下尿管の切開のみでは必ずしも VUR 発現はみられ ないと考觉られる。

以上，ヒトと家鬼の神経支配，構造上の差異はある にしても，本実験は現在おこなわれている各種尿管鏡 操作の，ヒト尿管に対する安全性をある程度示したも のとしてよいのではないかと考兄られた。

\section{結 語}

1. 家鬼を以下の 3 群にわけて，尿管口に対する拡 張, 切開操作による尿路系への影響について検討した。

1) $10 \mathrm{~F}$ 拡張群

2) $7 \mathrm{~F}$ 拡張群

3）切開群

各群 12 羽ずつ実験に使用した。

2。X 線学的検索として, 術後 1 日目, 3 日目および 1，2，4，8 週目にて膀胱造影，IVUを施行した。

VUR 発現に関する検索では, $10 \mathrm{~F}$ 拡張群では12例 中 8 例に認め，VURのない 4 例を含む 10 例に上部尿 路の拡張を認めた. $7 \mathrm{~F}$ 拡張群おょび切開群では, VUR が発現したものはなかった。

3。病理組織学的検索については, X 線学的検索直 後の膀胱を摘出して検討した。 $10 \mathrm{~F}$ 拡張群では過度の 拡張により, 尿管壁の断裂による筋層の損傷, 線維化 が認められた。さらに対照群に比して $10 \mathrm{~F}$ 拡張群では， 壁内尿管筋層の尿管全層に対する面積比は有意に減少
していた。これに比較して, 7F 拡張群および切開群で は，壁内尿管の組織学的変化は軽微であった。

4. 七上尿管と家鬼尿管との比較検討上, 尿管内径と 拡張との比率からみると, 家鬼尿管 $10 \mathrm{~F}$ 拡張は七トに あてはめると過度の拡張を負荷していると思われる。 家鬼尿管7F 拡張は, 拡張の程度からみてヒトに拈ける 尿管鏡施行時の通常の尿管口拡張操作にほぼ相当する ものと推測される。

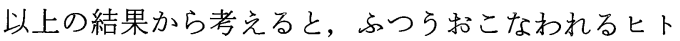
尿管口拡張および切開操作では, 尿路系への影響は少 なく, 安全性にも浪汇問題ないものと推測される。

稿を終えるにあたり, 御指導, 御校閲をいただいた恩師秋 元成太教授に心より感謝致します。また，御援助，御協力を いただいた日本医科大学第 2 病理学教室浅野伍朗教授, 同 泌尿器科学教室西村泰司助教授, 杉澤 裕医員, 本田了医 員, 木村 剛医員ならびに各位に厚く御礼申し上げます。

\section{文献}

1) Lyon, E.S., Huffman, J.L. and Bagley, D.H. Ureteroscopy and ureteropyeloscopy. Urology., 23, 29-36, 1984.

2) Stackl, W. and Marberger, M.: Late sequelae of themanagement of ureteral calculi with the ureterorenoscopy. J. Urol., 136, 386-389, 1986.

3) International Reflux Study Committee: Medical versus surgical treatment of primary vesicoureteral reflux: A prospective international reflux study in chilidren. J. Urol., 125, 277-283, 1981.

4) Pertz-Castero, E.E. and Martinez-Pineiro, J.A. : Transurethral ureteroscopy: A curent urological procedure. Arch. Esp. Urol., 33, 445 -460 。

5) Huffman, J.L., Bagley, D.H. and Lyon, E.S.: Treatment of distal ureteral calculiusi using a rigid ureteroscope. Urology, 20, 547-577, 1982.

6) Carter, S.C. St., Cox, R. and Wickham, j.E.A. : Complications associated with ureteroscopy. Brit. J. Urol., 58, 625-628, 1986.

7）板谷宏须：原発性膀胼尿管逆流に括ける膀胱壁内 尿管に関する研究. 日泌尿会誌, 68, 59-70, 1977.

8) Stephens, F.D. and Lenagham, D.: The anatomical basis and dynamics of vesicoureteral reflux. J. Urol., 87, 669-680, 1962.

9) Witherington, R.: Experimental study on role of intravesical ureter in vesicoureteral regurgitation. J. Urol., 89, 176-179, 1963.

10) Ross, G.J. and Thompson, I.M.: The relationship of non-obstructive reflux and chronic pyelonephritis : An experimental study. J. Urol., 
90, 391-394, 1963

11) Scott, J.E.S. and De Luca, F.G.: An experimental study of the lower end of the ureter and ureterovesical junction in dogs. Brit. J. Urol., 32, 216-223, 1960 .

12) SScott, J.E.S. and De Luca, F.G.: Urether studies on the ureterovesical junction of the dog. Brit. J. Urol., 32, 320-323, 1960.
13) Roberts, J.B.M. and Roylance, J.: Vesicoureteric reflux in man. Brit. J. Surg., 58, 889-892, 1966.

14）滝本至得：尿管膀胼移行部の筋構築について。 日 泌尿会誌，60，678-688，1969.

15）酒井 晃：膀胼尿管逆流現象の発生機序に関する 実験的研究。日泌尿会誌，64，238-251，1973.

（1987年11月 10 日受理，特別掲載） 